\title{
Analisis Perbelanjaan Asas Bulanan Penjawat Awam di Daerah Larut Matang dan Selama, Negeri Perak
}

\author{
Analysis of Government Servants' Monthly Basic Expenditures \\ in the District of Larut Matang and Selama, Perak State \\ Noor Al-Huda Abdul Karima , Norimah Rambeli@Ramli ${ }^{b}$, \\ Asmawi Hashim ${ }^{\mathrm{c}}$, Emilda Hashim ${ }^{\mathrm{d}}$, Nur Hayati Mohd Kornin ${ }^{\mathrm{e}}$ \\ a-eUniversiti Pendidikan Sultan Idris, Malaysia,nooralhuda@fpe.upsi.edu.my
}

\begin{abstract}
Abstrak
Penjawat awam mempunyai pendapatan bulanan yang tetap. Tetapi kos sara hidup yang semakin tinggi di Malaysia menyebabkan mereka melakukan pekerjaan sampingan untuk meningkatkan pendapatan keluarga. Kajian ini menumpukan kepada empat komponen perbelanjaan utama penjawat awam iaitu pendidikan, pemilikan harta, keagamaan dan kesihatan. Analisis dijalankan terhadap perbelanjaan bulanan barangan keperluan asas mereka mengikut jantina dan tahap pendidikan. Seramai 150 telah dipilih sebagai responden dalam kalangan penjawat awam dari Daerah Larut Matang dan Selama, Perak. Analisis deskriptif, ujian-t dan anova satu hala telah digunakan. Keputusan menunjukkan perbelanjaan terhadap pendidikan adalah yang paling tinggi berbanding dengan komponen-komponen perbelanjaan yang lain iaitu pemilikan harta, agama dan moral serta kesihatan. Perbelanjaan asas barangan dapur, pakaian dan pendidikan keluarga mempunyai corak perbelanjaan yang berbeza antara jantina. Bagi semua jenis perbelanjaan asas, penjawat awam mempunyai corak yang sama walaupun tahap pendidikan mereka adalah berbeza-beza.
\end{abstract}

Kata kunci: perbelanjaan asas, penjawat awam, pendapatan

\begin{abstract}
Government servants have fixed monthly income. But the higher cost of living of society in Malaysia causes them to do side jobs to increase their family income. This study focuses four main factors of expenditure namely, education, assets ownership, religiosity and health. Analysis was carried out on their monthly expenditures of basic necessity goods by sex and level of education. There were 150 civil servants as respondents from the District of Larut Matang and Selama, Perak selected.Descriptive analysis, $t$-Test and One-way ANOVA were used in the analysis. The results showed that their education expenditure was the highest compared to the others namely, assets ownership, religion and moral, and health. Basic expenditures on kitchen items, clothes and family education did not have the same pattern between sexes. For all types of basic expenditures, the civil servants had the same pattern, even though they had different levels of education.
\end{abstract}

Keywords: basic expenditures, civil servants, income

\section{LATAR BELAKANG KAJIAN}

Seringkali dikatakan penjawat awam tidak mempunyai gaji atau pendapatan bulanan yang cukup untuk mereka berbelanja. Bagi mereka, pendapatan yang diperoleh tiada lebihan untuk bersosial bersama keluarga atau meluangkan masa untuk pergi melancong. Kajian ini berkaitan dengan corak perbelanjaan penjawat awam terhadap barangan keperluan asas setiap bulan untuk keluarga mereka. Ia meliputi barangan yang berkaitan dengan pendidikan, kesihatan, keagamaan dan pemilikan harta. Perbezaan dari aspek jantina dan tahap pendidikan telah 
diambil kira. Ia dijalankan di Daerah Larut Matang dan Selamadalam negeri Perak. Antara kakitangan kerajaan yang terlibat dalam kajian ini adalah mereka yang bekerja di Wisma Perbandaran Taiping, Agensi Anti Dadah kebangsaan, Pejabat Daerah dan Tanah, Jabatan Kerja Raya (JKR), Wisma Persekutuan Taiping, Amanah Ikhtiar serta Jabatan Ensolvensi yang terdapat di bandar Taiping. Jumlah keseluruhan penduduk di daerah ini ialah 3.26 juta orang yang terdiri dari pelbagai peringkat umur.

Dua hipotesis yang dikaji iaitu pertama, tidak terdapat perbezaan antara jantina terhadap corak perbelanjaan keperluan asas bagi barangan dapur, pakaian, bil air, bil elektrik, bil telefon, pengangkutan awam, pengangkutan sendiri, barangan dan perkhidmatan lain serta faktor perbelanjaan pendidikan penjawat awam. Hipotesis kedua, tidak terdapat perbezaan antara tahap pendidikan terhadap corak perbelanjaan keperluan asas bagi barangan yang sama seperti dalam hipotesis pertama.

\section{KAJIAN LEPAS}

Maslow (1954) mengatakan bahawa keperluan asas seperti makanan, perlindungan, pakaian, tempat tinggal perlu dipenuhi terlebih dahulu oleh individu sebelum kehendak dan keperluankeperluan yang lain dipenuhi. Di Malaysia, perkembangan ekonomi telah berjaya meninggikan pendapatan secara umumnya, tetapi perubahan ekonomi dunia telah mewujudkan keadaan inflasi disebabkan perbelanjaan hidup keluarga yang kian meningkat (Bailard, Biehl dan Kaiser, 1992). Dalam Jariah Masud (1982), pengetahuan tentang mutu kehidupan masyarakat perlu diterapkan agar masyarakat dapat menguruskan perbelanjaan dengan baik. Penyediaan pelbagai rancangan pembangunan masyarakat, cara mengurus perbelanjaan persendirian dan keluarga perlu didedahkan. Oleh kerana kehendak yang tidak terhad, sumber pendapatan keluarga yang terhad perlu diuruskan dengan cekap.

Kemiskinan dalam kalangan isi rumah di kawasan luar bandar merupakan masalah yang serius. Ketua isi rumah perlu memainkan peranan untuk memberi kesedaran pendidikan keluarga. Kemampuan membeli kelengkapan persekolahan anak-anak turut memberi kesan terhadap semangat dan motivasi belajar mereka di sekolah. Oleh itu, bahan bacaan dan keperluan sekolah seperti pakaian, kasut sekolah, peralatan menulis dan sebagainya merupakan keperluan asas untuk menggalakkan anak-anak belajar dengan lebih baik dan bersemangat tinggi. Dalam Siti Masayu (2008), keputusan kajian menunjukkan bahawa individu-individu yang tidak mempunyai pendidikan sempurna menyebabkan mereka terperangkap dengan kemiskinan. Oleh itu, modal insan yang berkemahiran perlu dilahirkan terutama bagi masyarakat Melayu di kawasan luar bandar untuk keluar dari belenggu kemiskinan.

Dalam Abdul Muhaimin (2009), konsep Islam terhadap merancang harta tidak hanya terbatas kepada tatacara mengurus perbelanjaan individu atau keluarga. Ia juga meliputi pengurusan dan perancangan yang sistematik terhadap kesejahteraan dunia dan akhirat. Pemilikan harta perlu diurus dengan baik agar tidak bercanggah dengan syarak kerana ia akan diadili di akhirat kelak. Harta dalam Islam tidak boleh dibazirkan dan dibelanjakan kepada perkara-perkara maksiat. Menurut Syamsul Fuad (2010) pula, peranan ibu bapa terhadap pendidikan keagamaan anak-anak sejak dari usia muda adalah untuk meningkatkan sikap beragama dalam kalangan mereka.Ia akan memberi kesan positif pada jangka masa panjang iaitu anak-anak akan berkelakuan baik, berakhlak dengan minda terbuka sehingga mereka menjadi dewasa. 
Menurut kajian Nor Aini dan Norlida Hanim (2011), golongan wanita lebih mementingkan perbelanjaan kesihatan berbanding lelaki. Wanita lebih suka membeli produk-produk kesihatan untuk menjaga kebersihan diri dan kecantikan. Lelaki kurang memberi perhatian dalam hal ini sebagaimana dibuktikan melalui program ceramah berkenaan isu-isu kesihatan. Penglibatan golongan lelaki dan kekerapan mereka untuk membuat pemeriksaan kesihatan berada pada tahap yang rendah. Maxwell (1999) pula menjalankan kajian mengenai kepenggunaan, perletakan harga yang tinggi dan kesannya terhadap budaya dan jantina. Di peringkat global, penjual perlu memberi pertimbangan terhadap pengetahuan pengguna dalam memproses maklumat mengenai harga. Antara yang dikaji ialah sikap pengguna tentang pengetahuan harga sama ada akan menyalahkan penjual sekiranya harga barangan di pasaran semakin meningkat atau tidak. Hasil kajian menunjukkan sikap yang berat sebelah antara lelaki dan perempuan terhadap kenaikan harga. Kajian ini boleh dikaitkan dengan bagaimana lelaki dan wanita mempunyai sikap berbeza dalam perbelanjaan barangan.

Siti Aisyah, Ishak dan Azizah (2004) pula mengkaji tentang faktor-faktor yang mempengaruhi proses membuat keputusan dalam kalangan pengguna di Johor Bahru. Lokasi kajian ialah di tiga buah pasaraya besar, iaitu Pasaraya Giant di Tampoi dan Plentong serta Pasaraya Carrefour. Seramai 480 orang responden yang terdiri daripada pengguna lelaki dan perempuan telah terlibat dalam kajian ini. Berdasarkan etnik, hasil kajian menunjukkan status perkahwinan, umur, tahap pendidikan dan taraf pekerjaan dalam kalangan responden tidak mempunyai perbezaan yang signifikan. Faktor utama yang mempengaruhi keputusan pengguna semasa melakukan aktiviti pembelian adalah faktor High Quality Conscious.

Dalam kajian Che Rugayah (2001), selain golongan yang sudah bekerja, pengurusan kewangan juga perlu diambil tahu oleh golongan pelajar iaitu peranan mereka dalam mengendalikan perbelanjaan harian. Kebanyakan mereka tiada pendedahan tentang cara-cara mengurus kewangan peribadi dengan betul. Kajian ini melibatkan 108 orang pelajar Sarjana Pendidikan (Teknikal) Semester Dua, Kolej Universiti Teknologi Tun Hussein Onn yang berusia antara 20 hingga 30 tahun. Keputusan kajian mendapati bahawa untuk menerapkan sikap perbelanjaan yang bijak serta pengurusan kewangan yang mantap dalam kalangan pelajar, bimbingan dan pendedahan pengurusan kewangan yang khusus adalah perlu untuk melatih diri mereka supaya dapat berbelanja dengan bijak.

\section{KAEDAH DAN ANALISIS KAJIAN}

Kaedah utama untuk mengumpul data ialah penggunaan borang soal selidik. Sebelum itu, maklumat berkaitan responden diperoleh di pejabat-pejabat kerajaan daerah Larut Matang dan Selama di bandar Taiping. Proses pengumpulan data ini menggunakan waktu bekerja responden. Masa yang diberikan adalah selama satu jam supaya tidak menganggu kerja-kerja pejabat mereka. Soal selidik digunakan kerana ia dapat diagih dengan cepat dan mudah. Maklumat yang ingin diperoleh juga lebih banyak. Pengkaji berjaya mengumpulkan kesemua 150 borang soal selidik yang sudah dijawab oleh mereka yang terbabit.

Data dianalisis dengan menggunakan statistik deskriptif, ujian-t dan anova satu hala digunakan dengan menggunakan perisian Statistical Package for Social Science (SPSS). Untuk mengetahui dengan jelas mengenai latar belakang responden, pengumpulan maklumat demografi diringkaskan dalam bentuk kekerapan dan peratusan. Statistik deskriptif digunakan untuk memperoleh min, kekerapan, titik tengah dan sisihan piawai. Bagi menentukan sama ada 
terdapat perbezaan yang signifikan sikap berbelanja pengguna terhadap kesihatan, pendidikan, pemilikan harta dan keagamaan, ujian-t digunakan. Seterusnya, untuk menentukan sama ada terdapat perbezaan yang wujud di antara taraf pendidikan dan corak perbelanjaan bulanan, ujian anova satu hala pula digunakan. Jadual 1 menunjukkan ujian SPSS yang dijalankan untuk mencapai objektif kajian, manakala Jadual 2 pula ialah interpretasi skor min.

\section{Jadual 1: Ujian SPSS dan Objektif}

\begin{tabular}{ll}
\hline Ujian SPSS Yang Dijalankan & Objektif \\
\hline Deskriptif & Mengenal pasti sikap berbelanja kakitangan \\
& kerajaan. \\
T-test & Mengenal pasti kecenderungan yang paling tinggi \\
& terhadap corak perbelanjaan kakitangan kerajaan. \\
& 1. Mengenal pasti perbelanjaan keperluan asas \\
kNOkitangan kerajaan mengikut jantina. \\
2. Mengenal pasti perbelanjaan keperluan asas \\
& kakitangan kerajaan mengikut tahap pendidikan. \\
\hline
\end{tabular}

Jadual 2: Interpretasi Skor Min

\begin{tabular}{ll}
\hline Skor Min & Tahap \\
\hline $0.00-1.67$ & Rendah \\
$1.68-3.34$ & Sederhana \\
$3.35-5.00$ & Tinggi \\
\hline
\end{tabular}

Sumber: Ramlee Ismail et al. (2014)

Kaedah statistik ujian-t dan ujian anova sehala adalah untuk menentukan perbezaan corak perbelanjaan barangan asas bulanan dari aspek jantina. Ia diperoleh melalui maklumat pengaruh faktor demografi terhadap sikap dan corak perbelanjaan responden. Menurut Ramlee, Jamal dan Hariri (2014), ujian-t ialah prosedur statistik yang digunakan untuk memeriksa jika terdapat perbezaan min antara sampel dengan min populasi atau sebaliknya, manakala ANOVA pula ialah analisis varian untuk memperoleh dua anggaran varian bagi populasi daripada data dan kemudiannya statistik daripada nisbah kedua-duanya dikira. Aras signifikan yang ditetapkan ialah pada $\leq 0.05$.

\section{Ujian ANOVA Satu Hala}

Kaedah ujian ANOVA Satu Hala adalah seperti berikut:

$\mathrm{a}=$ bilangan aras bagi pemboleh ubah bebas

$\mathrm{n}=$ bilangan semua cerapan

SS(Rawatan) - ukuran bagi variasi di antara sampel

SS(Ralat) - ukuran bagi variasi dalam sampel

- Nilai kritikal, $\mathrm{F}_{\alpha, \mathrm{a}-1, \mathrm{n}-\mathrm{a}}$

$$
\begin{aligned}
& \mathrm{SS}\left(\text { Jumlah) } \quad=\sum_{i=1}^{a} \sum_{j=1}^{n_{j}}\left(\mathrm{x}_{\mathrm{ij}}-\overline{\mathrm{x}}\right)^{2}=\sum_{\mathrm{i}=1}^{\mathrm{a}} \sum_{\mathrm{j}=1}^{\mathrm{n}_{\mathrm{i}}} \mathrm{x}_{\mathrm{ij}}^{2}-\mathrm{n} \overline{\mathrm{x}}^{2}\right. \\
& \mathrm{SS} \text { (Rawatan) }=\sum_{\mathrm{i}=1}^{\mathrm{a}} \mathrm{n}_{\mathrm{i}}\left(\overline{\mathrm{x}}_{\mathrm{i}}-\overline{\mathrm{x}}\right)^{2}=\sum_{\mathrm{i}=1}^{\mathrm{a}} \frac{\mathrm{T}_{\mathrm{i}}^{2}}{\mathrm{n}_{\mathrm{i}}}-\mathrm{n} \overline{\mathrm{x}}^{2}
\end{aligned}
$$




$$
\begin{aligned}
& \mathrm{SS} \text { (Ralat) }=\mathrm{SS}(\text { Jumlah })-\mathrm{SS}(\text { Rawatan }) \\
& \overline{\mathrm{x}}=\text { min keseluruhan cerapan }=\frac{\sum_{\mathrm{i}=1}^{\mathrm{a}} \sum_{\mathrm{j}=1}^{\mathrm{n}_{\mathrm{i}}} \mathrm{x}_{i j}}{\mathrm{n}}
\end{aligned}
$$

Ujian ANOVA Satu Hala ini membandingkan kumpulan dengan menganalisis perbandingan varian. Ia mengukur sumber variasi dalam data dan membandingkan saiz di antaranya. Variasi antara sampel ialah variasi yang disebabkan oleh perbezaan di antara min sampel dan min keseluruhan cerapan. Variasi dalam sampel pula ialah variasi yang disebabkan oleh perbezaan di antara nilai cerapan dan min dalam kumpulan sampel tersebut.

\section{Sampel Kajian}

Seramai 150 responden telah dipilih dengan dua syarat yang telah ditetapkan iaitu lokasi responden adalah terdiri daripada penjawat awam yang tinggal di bandar Taiping dan sudah berkahwin sahaja. Soal selidik diedarkan kepada mereka yang bekerja di beberapa buah pejabat kerajaan.

\section{KEPUTUSAN KAJIAN}

Daripada 150 orang responden yang terdiri daripada penjawat awam di daerah Larut Matang dan Selama, Taiping, Perak, 75 orang responden adalah lelaki dan 75 orang responden lagi adalah perempuan. Jadual 3 menunjukkan keboleh percayaan item dengan nilai Cronbach's Alpha 0.731. Ia bermaksud kejituan yang sederhana tinggi dan item boleh digunakan untuk soal selidik dalam kajian yang sebenar.

Jadual 3: Keboleh Percayaan Kajian

\begin{tabular}{cc}
\hline Cronbach's Alpha & Keboleh Percayaan (n) \\
\hline .731 & 40 \\
\hline
\end{tabular}

\section{Profil Responden}

Jadual 4 menunjukkan taburan demografi responden dari aspek jantina, umur, status perkahwinan, kaum, agama, bilangan anak sudah bekerja atau bersekolah dan bilangan isi rumah tidak bekerja.

Jadual 4: Profil Demografi Responden (n=150)

\begin{tabular}{lcc}
\hline Item & Kekerapan & Peratus (\%) \\
Jantina & & \\
Lelaki & 75 & 50 \\
Perempuan & 75 & 50 \\
& & \\
\hline
\end{tabular}




\begin{tabular}{lcc}
\hline Umur & 2 & \\
Bawah 20 Tahun & 18 & 1.3 \\
21 Hingga 25 Tahun & 27 & 12.0 \\
26 Hingga 30 Tahun & 29 & 19.3 \\
31 Hingga 35 Tahun & 19 & 12.7 \\
36 Hingga 40 Tahun & 16 & 10.7 \\
41 Hingga 45 Tahun & 10 & 6.7 \\
46 Hingga 50Tahun & 23 & 15.3 \\
51 Hingga 55 Tahun & 6 & 4.0 \\
56 Hingga 60 Tahun & & \\
Status Perkahwinan & 148 & 98.7 \\
Sudah Berkahwin & 2 & 1.3 \\
Bercerai &
\end{tabular}

$\begin{array}{lcc}\text { Kaum } & & 98 \\ \text { Melayu } & 147 & 0 \\ \text { Cina } & 0 & 2 \\ \text { India } & 3 & \\ & & 98 \\ \text { Agama } & 147 & 2 \\ \text { Islam } & 3 & 0 \\ \text { Hindu } & 0 & 0 \\ \text { Buddha } & 0 & \\ \text { Kristian } & & 22.1 \\ \text { Anak Sudah Bekerja/Bersekolah } & 33 & 54.7 \\ \text { Sudah Bekerja } & 82 & 40.7 \\ \text { Masih Bersekolah } & 61 & 62 \\ \text { Belum Bersekolah } & & \\ \text { Bilangan Isirumah Tidak Bekerja } & 93 & \end{array}$

Catatan: $\mathrm{n}$ ialah bilangan

Berdasarkan umur, jumlah tertinggi ialah 29 orang (19.3\%) responden berumur 31-35 tahun dan diikuti 27 orang (18\%) responden berumur 26-30 tahun. Jumlah terendah ialah 2 orang (1.3\%) berumur di bawah 20 tahun. Seramai 148 orang (98.7\%) responden masih memegang status berkahwin, manakala 2 orang (1.3\%) responden yang lain telah bercerai. Bagi analisis kaum, Melayu menunjukkan jumlah tertinggi iaitu 147 orang (98\%) responden dan terendah ialah kaum India iaitu seramai 3 orang (2\%) sahaja. Seramai 147 orang $(98 \%)$ responden adalah beragama Islam, manakala 3 orang $(2 \%)$ beragama Hindu. Analisis negeri kelahiran responden pula menunjukkan jumlah tertinggi adalah dari negeri Perak iaitu 119 orang (79.3\%) dan terendah adalah dari Selangor, Kelantan dan Sabah, masing-masing hanya seorang $(0.7 \%)$ responden sahaja. Jumlah responden yang mempunyai anak masih bersekolah adalah tertinggi iaitu 82 orang $(54.7 \%)$ manakala terendah ialah $33(22.1 \%)$ orang responden yang mempunyai anak sudah bekerja.

Berkaitan sosioekonomi responden, analisis kajian menunjukkan daripada 150 orang responden, jumlah tertinggi ialah mereka yang mempunyai pendidikan tahap Sijil Profesional 
iaitu 46 orang (30.7\%), diikuti oleh 36 orang (24\%) berkelulusan Sijil Pelajaran Malaysia (SPM). Jumlah terendah ialah 2 orang (1.3\%) responden yang mempunyai pendidikan pada peringkat Sarjana Muda dan 2 orang (1.3\%) pada peringkat Sarjana. Bagi analisis jenis pekerjaan, kumpulan sokongan 2 (SPM) mencatatkan jumlah responden tertinggi iaitu seramai 85 orang $(56.7 \%)$. Hanya 3 orang $(3 \%)$ yang mempunyai jenis pekerjaan tahap pengurusan tertinggi. Bagi analisis tempoh berkhidmat, seramai 45 orang $(30 \%)$ responden baru berkhidmat 1 hingga 5 tahun dan merupakan responden tertinggi untuk tempoh bekerja, manakala jumlah terendah adalah bagi tempoh berkhidmat 36 hingga 40 tahun iaitu 4 orang (2.7\%) sahaja.Bagi analisis jumlah pendapatan, kajian menunjukkan jumlah terendah ialah 2 orang $(1.3 \%)$ responden yang berada dalam kategori pendapatan RM1000 dan kebawah. Bilangan responden yang mempunyai jumlah pendapatan RM1501 hingga RM2000 adalah seramai 52 orang $(34.7 \%)$ dan merupakan jumlah responden tertinggi untuk tingkat pendapatan.

Seterusnya ialah analisis jenis pendapatan sampingan. Masih ramai penjawat awam yang tidak mempunyai pendapatan sampingan iaitu seramai 67 orang $(44.7 \%)$ responden. Mereka yang menerima elaun daripada kerajaan adalah seramai 37 orang (24.7\%). Mereka yang mempunyai pendapatan melalui kereta sewa dan menjahit pula masing-masing seramai 2 orang $(1.3 \%)$. Manakala kategori berniaga di pasar malam dan yang menerima faedah pula, masing-masing seorang responden sahaja $(0.7 \%)$. Jumlah responden yang memperoleh jumlah pendapatan sampingan RM500 dan ke bawah adalah seramai 46 orang (30.7\%). Seramai 19 orang (12.7\%) responden yang lain pula mempunyai jumlah pendapatan RM501 hingga RM1000. Jumlah pendapatan sampingan antara RM2001 hingga RM 2500 serta antara RM2501 hingga RM 3000 masing-masing seramai 2 orang $(1.3 \%)$.

Jadual 5: Ujian-t bagi Faktor Barangan Dapur

\begin{tabular}{lllllll}
\hline & Jantina & Min & SP & t & dk & P \\
\hline $\begin{array}{l}\text { Barangan } \\
\text { Dapur }\end{array}$ & Lelaki & 4.09 & 248.775 & 2.548 & 148 & .009 \\
& Perempuan & 3.22 & 160.271 & & & \\
\hline
\end{tabular}

Dalam Jadual 5, analisis ujian-t menunjukkan perbezaan yang signifikan antara penjawat awam lelaki dan perempuan bagi faktor barangan dapur. Nilai $\mathrm{t}(148)=2.548, \mathrm{p}=0.009(\mathrm{p}<0.05)$. Perbezaan yang signifikan tersebut dibuktikan oleh nilai p yang lebih kecil daripada 0.05 .

Jadual 6: Ujian-t bagi Faktor Pakaian

\begin{tabular}{lllllll}
\hline & Jantina & Min & SP & t & dk & P \\
\hline Pakaian & Lelaki & 137.6 & 114.063 & 1.447 & 148 & 0.019 \\
& Perempuan & 114.2 & 80.609 & & & \\
\hline
\end{tabular}

Dalam Jadual 6, analisis ujian-t juga menunjukkan perbezaan yang signifikan berdasarkan jantina bagi faktor pakaian. Nilai $\mathrm{t}(148)=1.447, \mathrm{p}=0.019(\mathrm{p}<0.05)$. Nilai $\mathrm{p}$ ini adalah lebih kecil daripada 0.05 . Ini menunjukkan terdapat perbezaan yang signifikan tersebut.

Jadual 7: Ujian-t bagi Faktor Bil Air

\begin{tabular}{lllllll}
\hline & Jantina & Min & SP & t & dK & P \\
\hline Bil Air & Lelaki & 51.93 & 71.004 & 1.027 & 148 & .271 \\
& Perempuan & 42.85 & 28.483 & & & \\
\hline
\end{tabular}


Dalam Jadual 7, analisis ujian-t menunjukkan tidak terdapat perbezaan yang signifikan berdasarkan jantina antara penjawat awam lelaki dan perempuan bgi faktor bil air. Nilai $\mathrm{t}(148)=1.027, \mathrm{p}=0.271$ ( $\mathrm{p}>0.05)$. Nilai $\mathrm{p}$ ini adalah lebih besar daripada 0.05 yang menunjukkan tiada perbezaan yang signifikan tersebut.

Jadual 8: Ujian-t bagi Faktor Bil Elektrik

\begin{tabular}{lllllll}
\hline & Jantina & Min & SP & t & dk & P \\
\hline Bil Elektrik & Lelaki & 70.69 & 56.981 & -0.28 & 148 & .390 \\
& Perempuan & 70.97 & 65.527 & & & \\
\hline
\end{tabular}

Jadual 9: Ujian-t bagi Faktor Bil Telefon

\begin{tabular}{lllllll}
\hline & Jantina & Min & SP & t & dk & P \\
\hline \multirow{2}{*}{ Bil Telefon } & Lelaki & 85.39 & 51.991 & 1.087 & 148 & .343 \\
& Perempuan & 77.04 & 41.458 & & & \\
\hline
\end{tabular}

Jadual 10: Ujian-t bagi Faktor Pengangkutan Awam

\begin{tabular}{lllllll}
\hline & Jantina & Min & SP & t & dk & P \\
\hline $\begin{array}{l}\text { Pengangkutan } \\
\text { Awam }\end{array}$ & Lelaki & 3.84 & 25.10 & -0.59 & 148 & .927 \\
& & & & & & \\
\hline
\end{tabular}

Jadual 11: Ujian-t bagi Faktor Pengangkutan Sendiri

\begin{tabular}{lllllll}
\hline & Jantina & Min & SP & t & dk & P \\
\hline $\begin{array}{l}\text { Pengangkutan } \\
\text { Sendiri }\end{array}$ & Lelaki & 241.47 & 123.405 & 1.508 & 148 & 0.342 \\
& & & & & & \\
& Perempuan & 212.80 & 109.007 & & & \\
\hline
\end{tabular}

Jadual 12: Ujian-t bagi Faktor Barangan dan Perkhidmatan Lain

\begin{tabular}{lllllll}
\hline & Jantina & Min & SP & t & dk & P \\
\hline $\begin{array}{l}\text { Barangan dan } \\
\begin{array}{l}\text { Perkhidmatan } \\
\text { lain }\end{array}\end{array}$ & Lelaki & 216.00 & 171.866 & 1.196 & 148 & 0.093 \\
& & & & & & \\
& Perempuan & 186.93 & 121.344 & & & \\
\hline
\end{tabular}

Begitu juga dalam Jadual 8, Jadual 9, Jadual 10, Jadual 11 dan Jadual 12, analisis ujian-t menunjukkan tiada perbezaan yang signifikan berdasarkan jantina antara pejawat awam lelaki dan perempuan bagi faktor-faktor bil elektrik, bil telefon, pengangkutan awam, faktor pengangkutan sendiri dan faktor barangan dan perkhidmatan lain.

Jadual 13: Ujian-t bagi Faktor Perbelanjaan Pendidikan Keluarga

\begin{tabular}{lllllll}
\hline & Jantina & Min & SP & t & dk & P \\
\hline $\begin{array}{l}\text { Perbelanjaan } \\
\begin{array}{l}\text { Pendidikan } \\
\text { Keluarga }\end{array}\end{array}$ & Lelaki & 284.40 & 300.087 & 1.393 & 148 & 0.014 \\
& & & & & & \\
& Perempuan & 224.13 & 224.259 & & & \\
\hline
\end{tabular}


Dalam Jadual 13, analisis ujian-t menunjukkan terdapat perbezaan yang signifikan berdasarkan jantina bagi faktor perbelanjaan pendidikan keluarga. Nilai $t(148)=1.393, p=0.014(p<0.05)$. Nilai p adalah lebih kecil daripada 0.05 .

\section{Analisis Anova}

Ujian Anova sehala dijalankan bagi melihat sama ada terdapat perbezaan yang signifikan antara corak perbelanjaan asas bulanan dengan tahap pendidikan.

Jadual 14: Faktor Barangan Dapur Berdasarkan Tahap Pendidikan (n=150)

\begin{tabular}{lll} 
Tahap Pendidikan & Min & SP \\
\hline Sekolah Rendah & 250.00 & 83.666 \\
SRP/PMR & 373.53 & 198.187 \\
SPM & 387.50 & 217.247 \\
STPM & 385.83 & 267.053 \\
Sijil Profesional & 345.67 & 240.529 \\
Diploma & 395.83 & 138.922 \\
Sarjana Muda & 300.00 & 141.421 \\
Sarjana & 450.00 & 70.711 \\
Jumlah & 366.21 & 213.076 \\
\hline
\end{tabular}

Catatan: $\mathrm{n}$ ialah bilangan

\begin{tabular}{llllll}
\hline Punca Variasi & JKD & dk & MKD & F & P \\
\hline Antara Kumpulan & 156527.681 & 7 & 22361.097 & .480 & .848 \\
Dalam Kumpulan & 6608274.913 & 142 & 46537.147 & & \\
Jumlah & 6764802.594 & 149 & & & \\
\hline
\end{tabular}

Berdasarkan Jadual 14, tiada perbezaan yang signifikan antara corak perbelanjaan faktor barangan dapur berdasarkan tahap pendidikan. Nilai min keseluruhan $\mathrm{F}=0.480, \mathrm{p}=0.848$ ( $>0.05$ ). Secara statistik, ini adalah kerana p lebih besar daripada 0.05.

Jadual 15: Faktor Pakaian Berdasarkan Tahap Pendidikan (n=150)

\begin{tabular}{lcc}
\hline Tahap Pendidikan & Min & SP \\
\hline Sekolah Rendah & 130.00 & 11.355 \\
SRP/PMR & 112.06 & 64.937 \\
SPM & 123.89 & 94.090 \\
STPM & 128.33 & 143.770 \\
Sijil Profesional & 135.22 & 119.865 \\
Diploma & 133.33 & 68.534 \\
Sarjana Muda & 90.00 & 84.853 \\
Sarjana & 150.00 & 70.711 \\
Jumlah & 125.93 & 99.124 \\
\hline
\end{tabular}

Catatan: $\mathrm{n}$ ialah bilangan 


\begin{tabular}{llllll}
\hline Antara Kumpulan & 15226.736 & 7 & 2175.248 & 213 & .982 \\
Dalam Kumpulan & 1448792.597 & 142 & 10202.765 & & \\
\hline Jumlah & 1464019.333 & 149 & & & \\
\hline
\end{tabular}

Jadual 16: Faktor Bil Air Berdasarkan Tahap Pendidikan (n=150)

\begin{tabular}{|c|c|c|c|c|c|}
\hline Tahap Pendidikan & & & Min & SP & \\
\hline Sekolah Rendah & & & 41.67 & 18.348 & \\
\hline SRP/PMR & & & 47.06 & 31.070 & \\
\hline SPM & & & 44.47 & 26.759 & \\
\hline STPM & & & 53.33 & 50.513 & \\
\hline Sijil Profesional & & & 51.37 & 86.502 & \\
\hline Diploma & & & 42.08 & 30.411 & \\
\hline Sarjana Muda & & & 40.00 & 14.142 & \\
\hline Sarjana & & & 35.00 & 21.213 & \\
\hline Jumlah & & & 47.39 & 54.133 & \\
\hline Catatan: $\mathrm{n}$ ialah bilang & & & & & \\
\hline Punca Variasi & JKD & dk & MKD & $\mathbf{F}$ & $\mathbf{P}$ \\
\hline Antara Kumpulan & 2413.305 & 7 & 344.758 & 113 & .997 \\
\hline Dalam Kumpulan & 434208.489 & 142 & 3057.806 & & \\
\hline Jumlah & 436621.793 & 149 & & & \\
\hline
\end{tabular}

Jadual 17: Faktor Bil Elektrik Berdasarkan Tahap Pendidikan (n=150)

\begin{tabular}{|c|c|c|c|c|c|}
\hline Tahap Pendidikan & & & Min & SP & \\
\hline Sekolah Rendah & & & 79.83 & 77.150 & \\
\hline SRP/PMR & & & 70.59 & 36.009 & \\
\hline SPM & & & 72.50 & 59.779 & \\
\hline STPM & & & 99.17 & 108.415 & \\
\hline Sijil Profesional & & & 52.02 & 36.663 & \\
\hline Diploma & & & 105.25 & 107.364 & \\
\hline Sarjana Muda & & & 75.00 & 35.335 & \\
\hline Sarjana & & & 70.00 & 42.426 & \\
\hline \multicolumn{6}{|c|}{ Catatan: $\mathrm{n}$ ialah bilangan } \\
\hline Punca Variasi & JKD & dk & MKD & $\mathbf{F}$ & $\mathbf{P}$ \\
\hline Antara Kumpulan & 40749.870 & 7 & 5821.410 & 1.598 & 0.141 \\
\hline Dalam Kumpulan & 517252.964 & 142 & 3641.627 & & \\
\hline Jumlah & 558002.834 & 149 & & & \\
\hline
\end{tabular}

Jadual 18: Faktor Bil Telefon Berdasarkan Tahap Pendidikan $(n=150)$

\begin{tabular}{lll}
\hline Tahap Pendidikan & Min & SP \\
\hline Sekolah Rendah & 63.17 & 28.216 \\
SRP/PMR & 80.29 & 41.814 \\
SPM & 94.17 & 60.869 \\
STPM & 69.00 & 52.650 \\
Sijil Profesional & 77.07 & 43.698 \\
Diploma & 85.00 & 28.445 \\
Sarjana Muda & 70.00 & 28.284 \\
Sarjana & 75.00 & 35.335 \\
\hline Jumlah & 81.21 & 47.049 \\
\hline
\end{tabular}


Catatan: $\mathrm{n}$ ialah bilangan

\begin{tabular}{llllll} 
Punca Variasi & JKD & dk & MKD & F & P \\
\hline Antara Kumpulan & 11105.477 & 7 & 1586.497 & & \\
Dalam Kumpulan & 318723.697 & 142 & 2244.533 & .707 & .666 \\
\hline Jumlah & 329829.174 & 149 & & & \\
\hline
\end{tabular}

Jadual 19: Faktor Pengangkutan Awam BerdasarkanTahap Pendidikan (n=150)

\begin{tabular}{|c|c|c|c|c|c|}
\hline Tahap Pendidikan & & & Min & SP & \\
\hline Sekolah Rendah & & & 0.00 & 0.000 & \\
\hline SRP/PMR & & & 6.03 & 27.683 & \\
\hline SPM & & & 5.56 & 33.333 & \\
\hline STPM & & & 0.00 & 0.000 & \\
\hline Sijil Profesional & & & 4.09 & 4.09 & \\
\hline Diploma & & & 0.00 & 0.00 & \\
\hline Sarjana Muda & & & 0.00 & 0.00 & \\
\hline Sarjana & & & 0.00 & 0.000 & \\
\hline \multicolumn{6}{|c|}{ Catatan: $\mathrm{n}$ ialah bilangan } \\
\hline Punca Variasi & JKD & $\mathbf{d k}$ & MKD & $\mathbf{F}$ & $\mathbf{P}$ \\
\hline Antara Kumpulan & 771.162 & 7 & 110.166 & .193 & .987 \\
\hline Dalam Kumpulan & 81153.512 & 142 & 571.504 & & \\
\hline Jumlah & 81924.674 & 149 & & & \\
\hline
\end{tabular}

Jadual 20: Faktor Pengangkutan Sendiri Berdasarkan Tahap Pendidikan (n=150)

\begin{tabular}{|c|c|c|c|c|c|}
\hline Tahap Pendidikan & & & Min & \multicolumn{2}{|c|}{ SP } \\
\hline Sekolah Rendah & & & 251.67 & \multicolumn{2}{|c|}{149.722} \\
\hline SRP/PMR & & & 221.47 & \multicolumn{2}{|c|}{114.021} \\
\hline SPM & & & 260.83 & \multicolumn{2}{|c|}{112.234} \\
\hline STPM & & & 183.33 & \multicolumn{2}{|c|}{100.755} \\
\hline Sijil Profesional & & & 204.13 & \multicolumn{2}{|c|}{123.136} \\
\hline Diploma & & & 254.17 & \multicolumn{2}{|c|}{115.716} \\
\hline Sarjana Muda & & & 250.00 & \multicolumn{2}{|c|}{70.711} \\
\hline Sarjana & & & 250.00 & \multicolumn{2}{|c|}{70.711} \\
\hline \multicolumn{6}{|c|}{ Catatan: $\mathrm{n}$ ialah bilangan } \\
\hline Punca Variasi & JKD & dk & MKD & $\mathbf{F}$ & $\mathbf{P}$ \\
\hline Antara Kumpulan & 103808.979 & 7 & 14829.854 & \multirow{2}{*}{\multicolumn{2}{|c|}{1.089}} \\
\hline Dalam Kumpulan & 1933258.355 & 142 & 13614.495 & & \\
\hline Jumlah & 2037067.334 & 149 & & & \\
\hline
\end{tabular}


Jadual 21: Faktor Barangan dan Perkhidmatan Lain Berdasarkan Tahap Pendidikan (n=150)

\begin{tabular}{lll}
\hline Tahap Pendidikan & Min & SP \\
\hline Sekolah Rendah & 175.00 & 75.829 \\
SRP/PMR & 223.53 & 189.591 \\
SPM & 179.17 & 109.591 \\
STPM & 195.83 & 210.474 \\
Sijil Profesional & 207.61 & 145.284 \\
Diploma & 214.17 & 121.540 \\
Sarjana Muda & 200.00 & 141.421 \\
Sarjana & 125.00 & 35.355 \\
& & \\
Jumlah & 201.47 & 148.980 \\
\hline
\end{tabular}

Catatan: $\mathrm{n}$ iala bilangan

\begin{tabular}{llllll}
\hline Punca Variasi & JKD & dk & MKD & F & P \\
\hline Antara Kumpulan & 54405.573 & 7 & 7772.225 & & \\
Dalam Kumpulan & 325671.760 & 142 & 22906.139 & .339 & .935 \\
\hline Jumlah & 3307077.333 & 149 & & & \\
\hline
\end{tabular}

Jadual 22: Faktor Perbelanjaan Pendidikan Keluarga Berdasarkan

Tahap Pendidikan $(n=150)$

\begin{tabular}{lll}
\hline Tahap Pendidikan & Min & SP \\
\hline Sekolah Rendah & 191.67 & 180.046 \\
SRP/PMR & 261.76 & 270.493 \\
SPM & 298.61 & 263.982 \\
STPM & 170.83 & 186.424 \\
Sijil Profesional & 218.26 & 251.982 \\
Diploma & 387.50 & 390.876 \\
Sarjana Muda & 150.00 & 212.132 \\
Sarjana & 150.00 & 212.132 \\
Jumlah & 254.27 & 265.735 \\
\hline
\end{tabular}

Catatan: $\mathrm{n}$ ialah bilangan

\begin{tabular}{llllll}
\hline Punca Variasi & JKD & dk & MKD & F & P \\
\hline Antara Kumpulan & 495883.791 & 7 & 70840.542 & 1.003 & 0.432 \\
Dalam Kumpulan & $1.003 E 7$ & 142 & 70604.124 & & \\
\hline Jumlah & $1.0552 \mathrm{E} 7$ & 149 & & & \\
\hline
\end{tabular}

Begitu juga bagi Jadual 15 sehingga Jadual 22, tidak terdapat perbezaan yang signifikan antara corak perbelanjaan faktor pakaian, faktor bil air, faktor bil elektrik, faktor bil telefon, faktor pengangkutan awam, faktor pengangkutan sendiri, faktor barangan dan perkhidmatan lain, dan faktor perbelanjaan pendidikan keluarga dengan tahap pendidikan. Nilai p lebih daripada 0.05.

\section{Kecenderungan Perbelanjaan oleh Penjawat Awam Terhadap Pendidikan, Pemilikan Harta, Keagamaan dan Kesihatan.}

Daripada kajian ini. penjawat awam lebih cenderung berbelanja untuk barangan yang berkaitan faktor pendidikan. Ia adalah lebih tinggi berbanding dengan kecenderungan perbelanjaan 
terhadap tiga faktor yang lain. Nilai min bagi pendidikan adalah paling tinggi iaitu 3.78. Kecenderungan perbelanjaan terhadap keagamaan adalah kedua tertinggi dengan nilai min 3.70. Seterusnya, kecenderungan perbelanjaan kesihatan mencatatkan ketiga tertinggi iaitu dengan nilai min sebanyak 3.27 dan kecenderungan perbelanjaan terhadap pemilikan harta mencatatkan nilai min yang terendah iaitu 3.20. Kajian ini menunjukkan kebanyakan responden mengutamakan perbelanjaan terhadap pendidikan anak-anak terlebih dahulu, diikuti dengan perbelanjaan keagamaan keluarga, kesihatan dan perbelanjaan terhadap pemilikan harta.

\section{KESIMPULAN}

Keputusan kajian ini menunjukkan tiada perbezaan yang signifikan antara faktor corak perbelanjaan asas berdasarkan tahap pendidikan. Dalam keputusan yang lain pula, kecenderungan perbelanjaan oleh penjawat awam terhadap pendidikan adalah tertinggi antara semua jenis sikap kecenderungan perbelanjaan. Perbelanjaan pendidikan memainkan peranan yang penting untuk Malaysia mencapai status negara maju melalui Wawasan 2020. Seiring dengan dasar pembangunan dalam negara yang mementingkan kehidupan masyarakat berkualiti, ilmu pengetahuan, kemahiran dan kompetensi bekerja amat perlu untuk memberi kesan yang besar kepada kejayaan sosioekonomi negara. Tambahan pula, Malaysia perlu menghadapi persaingan ekonomi global pada masa kini dan akan datang. Sekurang-kurangnya, kajian ini dapat memberi satu gambaran mengenai corak perbelanjaan penjawat awam Malaysia melalui sampel kecil di lokasi Daerah Larut Matang dan Selama. Kajian dengan saiz sampel dan meliputi beberapa lokasi yang lebih besar dijangkakan untuk memberi hasil dapatan yang lebih kritikal pada masa akan datang.

\section{RUJUKAN}

Abdul Muhaimin Mahmood (2009).Tuntutan agama dalam membuat perancangan harta. Kertas kerja dalam Seminar Perancangan Harta Individu dan Harta Syarikat Islam, 30 Mei, Hotel Flamingo Ampang.

Bailard, T.E. \& Biehl, D.C.\& Kaiser, R.W. (1992). Personal money management. 6th. Edition. Science Research Association Inc. United States.

Che Rugayah Che Ismail. (2001). Pengurusan kewangan pelajar: satu tinjauan awal kepada keperluan kaunseling kewangan. Masters Thesis.Universiti Teknologi Tun Hussein Onn Malaysia.

Jariah Masud. (1982). Corak perbelanjaan dan pengurusan di kalangan beberapa keluarga Melayu dan Cina di Wilayah Persekutuan. Pertanika 5(1), 45-52.

Maslow A.IF. (1954). Motivation and personality. New York, Harper and Row Publishers.

Maxwell S. (1999). Biased attributions of a price increase: Effect of culture and gender. Journal of Consumer Marketing, 16 (1), 9 - 23.

Nor Aini Haji Idris dan Norlida Hanim Mohd Salleh. (2011). Faktor penentu perbelanjaan kesihatan di kalangan golongan bekerja. Dalam Prosiding Persidangan Kebangsaan Ekonomi Malaysia ke VI (PERKEM VI), 5-7 Jun, Melaka.

Ramlee Ismail, Jamal@ Nordin Yunus dan Hariri Kamis. (2014). Analisis data kuantitatif. Kaisar Media Kreatif, Kuala Lumpur.

Siti Aisyah Panatik, Ishak Mad Shah dan Azizah Rajab. (2004). Kajian terhadap proses membuat keputusan dalam tingkah laku membeli di kalangan pengguna: Kajian kes di Johor Bahru. Projek Penyelidikan.Research Vote No: 71897. Jabatan Pembangunan Sumber Manusia, Fakulti Pengurusan dan Pembangunan Sumber Manusia, Universiti Teknologi Malaysia. 
Siti Masayu Rosliah Abdul Rashid. (2008). Tesis Ijazah Sarjana. Peluang dan cabaran pendidikan dalam kalangan masyarakat luar bandar: satu kajian kes isirumah Melayu miskin di Jajahan Bachok, Kelantan.Universiti Sains Malaysia.

Syamsul Fuad (2010), Peranan orang tua dalam menanamkan sikap keberagamaan anak usia sekolah dasar.Tesis Ijazah Sarjana. Fakultas Ilmu Tarbiyah dan Keguruan Universitas Islam Syarif Hidayatullah. Jakarta. 